reprint from Islamic Culture, April, 1948, Mohd. Abdur Rahman Khan provides a short account of thirteen fireballs from A.D. 983 to A.D. $103 \mathrm{I}$; three comets from A.D. 974 to A.D. 1056 ; a comet in A.D. 1741, a detonating fireball in A.D. 1742, and another one in A.D. 1757 and an earthquake at the same time (it is conjectured that the earthquake may have been due to the impact of a large meteorite with the ground), and a slight earthquake in A.D. 1759. This information is additional to that published by the same author in his brochure "Meteoric Showers, Past and Present", some of which was discussed by him in the Islamic Culture Magazine, 20, 4 (1946).

\section{Scottish Conference on Road Research}

AN all-day conference to discuss road research problems will be held in Glasgow at the Royal Technical College on September 24. The conference is being called, with the collaboration of the Ministry of Transport, by Dr. W. H. Glanville, director of road research of the Department of Scientific and Industrial Research, in association with the Glasgow and District Association of the Institution of Civil Engineers, the Scottish branches of the Institution of Municipal Engineers and the County Surveyors' Society, and the Scottish Accident Prevention Council. The chairman of the conference will be Sir Patrick Dollan. The purpose of the conference is to bring the work of the Road Research Organisation before Scottish engineers and others concerned with roads and road traffic, and to provide an opportunity for discussing which research problems are of particular interest to Scotland. In addition to short papers by the director of road research and senior members of his staff, followed by an open discussion, there will be an exhibition of some aspects of the work of the Organisation. The morming session (deputy chairman : Colonel T. U. Wilson) will be devoted to materials and methods of construction, and the afternoon session (deputy chairman : Mr. G. J. Sherriff) to road safety and traffic flow. Owing to limitations of space, admission will be by ticket, obtainable from the Director of Road Research, Road Research Lab. oratory, Harmondsworth, West Drayton, Middlesex.

\section{University of London: Appointments}

THE following appointments in the University of London have recently been announced: Dr. T. Crawford, University professor of pathology in St. George's Hospital Medical School as from October 1. Since 1946 he has been director of pathological services at St. George's Hospital and Medical School; Mr. D. V. Davies, University professor of anatomy in St. Thomas's Hospital Medical School as from October 1. Since 1944 he has been fellow and College lecturer at St. John's College, Cambridge, and in 1945 was Arris and Gale Lecturer at the Royal College of Surgeons; Mr. A. V. Judges, University professor of history of education in King's College as from January 1, 1949. Since 1938 he has held the title of reader in economic history in the London School of Economics and Political Science; Dr. R. T. Williams, University professor of biochemistry in St. Mary's Hospital Medical School as from October 1. Since 1942 he has been senior lecturer in biochemistry and during 1943-44 was in charge of the Department of Biochemistry at the University of Birmingham; Dr. G. L. Clark, University reader in mathematies in Bedford College as from October 1. Since 1947 he has been senior lecturer in mathematics at University College, Cardiff; Mr. T. A. Rodger, University reader in psychology in Birkbeck College as from October 1. $\mathrm{He}$ is at present senior psychologist to the Admiralty, consulting psychologist to the Central Juvenile Employment Executive and a lecturer in Birkbeck College.

\section{Announcements}

Mr. Derek Allan Hough has been appointed general secretary of the Institute of Petroleum with effect from September 1. Mr. George Sell has been appointed as editor of the Institute's publications with effect from August 1. Mr. Sell has been publica. tions secretary since March, 1946.

Prof. Walter H. Bucher, of Columbia University, has been elected president of the American Geophysical Union to fill the unexpired term of the late Oscar E. Meinzer. This term will expire on June 30 , 1950.

Mr. F. A. SecretT has resigned his position as honorary adviser to the Ministry of Agriculture and Fisheries on vegetable production, with effect from August 1. Mr. Secrett, who is himself a leading vegetable grower, has held this appointment since August, 1942. He will continue his membership of the Agricultural Improvement Council.

IN recognition of his studies on "Sludged Blood" the College of Physicians of Philadelphia has awarded the Alvarenga Prize for this year to Dr. Melvin H. Knisely, of the University of Chicago. The Alvarenga Prize was established by the will of Pedro Francisco da Costa Alvarenga, of Lisbon, Portugal, an associate fellow of the College, "to be awarded annually by the College of Physicians on each anniversary of the death of the testator, July 14 , 1883".

THE Electronics Division of the U.S. Electrochemical Society is making preparations for a symposium on luminescence, to be held during its meeting in Philadelphia, from May 5 until 7, 1949. Further information can be obtained from Dr. R. M. Burns, Electrochemical Society, 235 West 102 Street, New York 25, New York.

THE Nuffield Foundation has provided funds for the establishment of a research fellowship in extraction metallurgy, which will be awarded in consultation with the Institution of Mining and Metallurgy and the Royal School of Mines, London, and will be tenable at the Royal School of Mines for a period of five years. The funds are sufficient to provide a small specialist staff and the necessary equipment in addition to adequate remuneration for the fellow. Further information can be obtained from the Secretary, the Institution of Mining and Metallurgy, Salisbury House, London, E.C.2.

THE Medical Research Council announces that it has awarded Rockefeller travelling fellowships in medicine to the following, for the academic year 1948-49: Dr. K. W. Donald, Medical Professorial Unit, St. Bartholomew's Hospital, London; Dr. L. P. R. Fourman, Nuffield Department of Clinical Medicine, University of Oxford; Dr. R. H. Girdwood, Department of Medicine, University of Edinburgh; Dr. A. Isaacs, Department of Medicine, University of Sheffield; Mr. A. I. S. Macpherson, Department of Surgery, University of Edinburgh; Dr. H. B. Stoner, Department of Pathology, University of Sheffield ; Mr. S. F. Taylor, Department of Surgery, Postgraduate Medical School, London. 